\title{
Excavations at Site 41CK193: Cultural Resource Investigations Along SH 158 West of the Town of Edith Coke County, Texas
}

Alan J. Wormser

Follow this and additional works at: https://scholarworks.sfasu.edu/ita

Part of the American Material Culture Commons, Archaeological Anthropology Commons, Environmental Studies Commons, Other American Studies Commons, Other Arts and Humanities Commons, Other History of Art, Architecture, and Archaeology Commons, and the United States History Commons

Tell us how this article helped you.

This Article is brought to you for free and open access by the Center for Regional Heritage Research at SFA ScholarWorks. It has been accepted for inclusion in Index of Texas Archaeology: Open Access Gray Literature from the Lone Star State by an authorized editor of SFA ScholarWorks. For more information, please contact cdsscholarworks@sfasu.edu. 


\section{Excavations at Site 41CK193: Cultural Resource Investigations Along SH 158 West of the Town of Edith Coke County, Texas}

\section{Licensing Statement}

This is a work produced for the Texas Department of Transportation (TxDOT) by the report producer. TxDOT and the report producer jointly own all rights, title, and interest in and to all intellectual property developed under TXDOT's contract with the report producer. The report may be cited and brief passages from this publication may be reproduced without permission provided that credit is given to both TXDOT and the report producer. Permission to reprint an entire chapter, section, figures or tables must be obtained in advance from either the Supervisor of the Archeological Studies Branch, Environmental Affairs Division, Texas Department of Transportation, 125 East 11th Street, Austin, Texas, 78701 or from the report producer. 
EXCAVATIONS AT SITE 41CK193:

CULTURAL RESOURCE INVESTIGATIONS ALONG SH 158

WEST OF THE TOWN OF EDITH

COKE COUNTY, TEXAS

Alan J. Wormser 
Test excavations were conducted at Site $41 \mathrm{CK} 193$ by members of the cultural resources staff at the Texas State Department of Highways and Public Transportation (SDHPT). The excavation was completed between November 17 and 19 , 1986, as part of a road improvement project along SH 158 in northwestern Coke County. A few cutting implements and a blade core were found by Wayne C. Young of the SDHPT in a general surface collection which he made in September of 1986. Subsequently, four 1 by 1 meter test units and a single 2 by 2 meter test unit were excavated by hand to depths of between 10 and $30 \mathrm{~cm}$ below the present surface. The large unit revealed a hearth feature, part of which was visible on the surface. The other test units resulted in the recovery of only a few flakes of chert and no other features were found. No artifacts were recovered with which to assign a firm date to the site. Road maintenance such as scraping along the right-of-way may have removed the upper portion of the site. However, the overall lack of material and features suggests that the site was an ephemeral campsite of limited function. It is not considered worthy of nomination to the National Register of Historic Places, nor to warrant State Archeological Landmark designation. 
TABLE OF CONTENTS

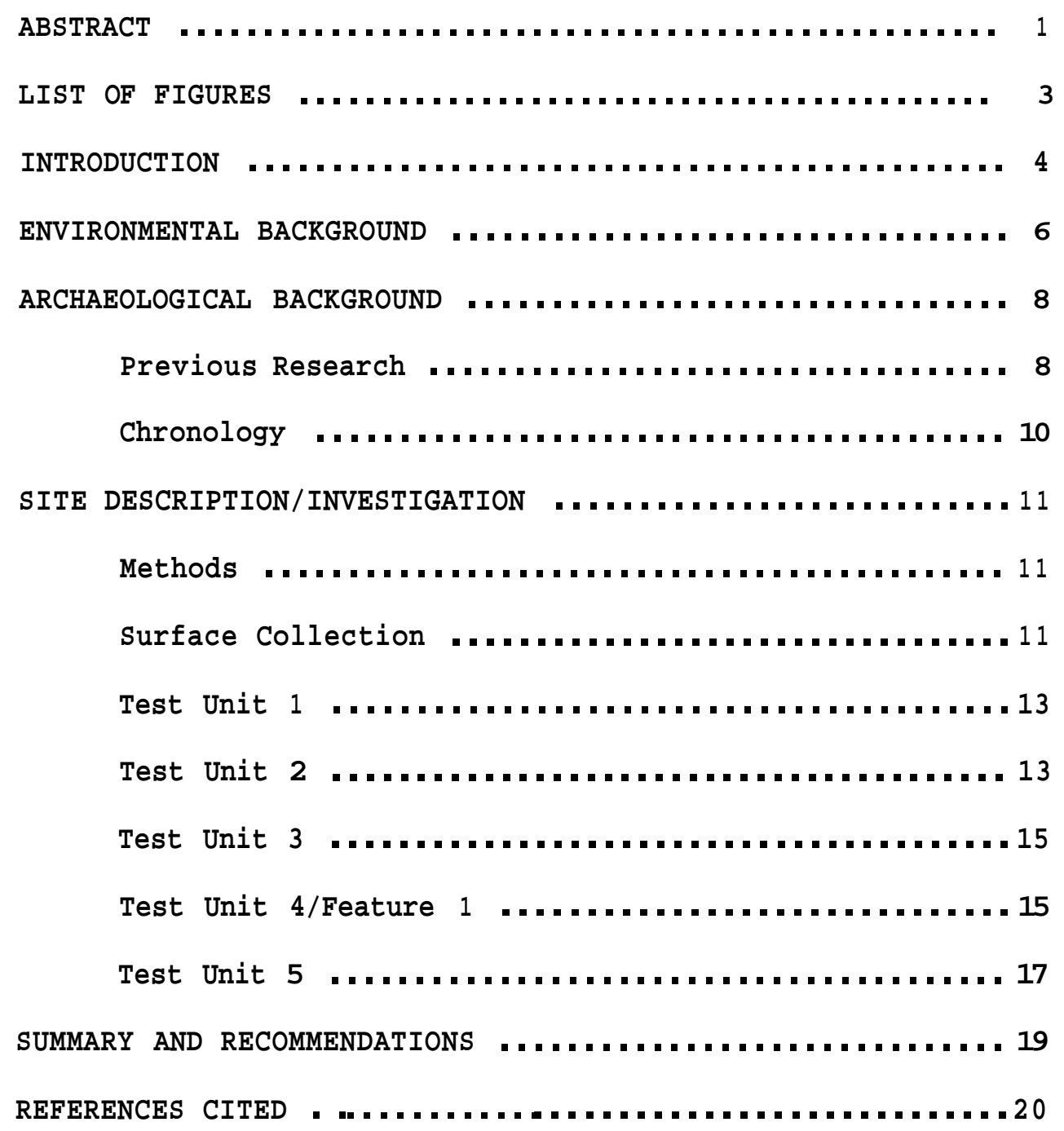


FIGURE 1. Location of Site 41CK193. Coke County. Texas ...... 5 FIGURE 2. Map of Site 41CK193 showing location of test units... 12 FIGURE 3. Artifacts from surface collection of 41CK193 ....... 14 FIGURE 4. Rock alignment from Test Units 3 and 5, Level 1 .... 16 FIGURE 5. Hearth feature from Test Unit $4 \ldots \ldots . \ldots 18$ 
INTRODUCTION

In November of 1986 , test excavations were conducted at 41CK193, a small

prehistoric campsite in Coke County, Texas, near the town of Edith. Testing of $41 \mathrm{CK} 193$ was performed by Alan J. Wormser and Wayne C. Young of the cultural resources staff of the State Department of Highways and Public Transportation (SDHPT). The SDHPT District 7 office supplied 4 maintenance staff members for the excavation crew: Luis Bernal, Gary Eilbrey, Ynes Lara, and Leonard Sanchez. All testing was conducted in the highway right-of-way under the Procedures for the Protection of Historic and Cultural Properties ( 36 CFR, Part 800). Field work consisted of a total of 7 man-days.

Site 41 CK193 is on a terrace of Pecan Creek near the confluence of Pecan Creek with Kate Creek in northwestern Coke County (Figure 1). It was first recorded as early as 1932, by E.B. Sayles. The site occurs along the right-of-way north and south of $\mathrm{SH} 158$, on the west side of the creek. The portion of the right-of-way nearest the bridge has been disturbed by bridge construction and maintenance activity, and little cultural material was found there. Road resurfacing and widening along SH 158 (all within the present right-of-way) necessitated the testing of $41 \mathrm{CK} 193$ to determine its eligibility for nomination to the National Register of Historic Places and the significance of the site to the state's archaeological resources. 
This Page Redacted Per THC Policy 
ENVIRONMENTAL BACKGROUND

The climate of Coke County is warm and subtropical, with a mean annual rainfall of 17.88 in. (Barnhill 1974:46). Daily temperatures vary between $34.3 \mathrm{~F}$ and $59.4 \mathrm{~F}$ in January, and between $72.6 \mathrm{~F}$ and $97.5 \mathrm{~F}$ in August (Barnhill 1974:48). Rainfall is typically highest in late spring and early autumn.

Small game in Coke County includes badger, red fox, gray fox, coyote, prairie dog, fox squirrel, plains pocket gopher, porcupine, jackrabbit, and cottontail. Deer is the only larger mammalian fauna common to Coke County today. Bison, pronghorn, javelina, and red wolf may have been more common in the past (Davis 1974).

Coke County is on the margin between the Rolling Plains and the Edwards Plateau vegetational areas (Gould 1969). Both areas are typically grasslands. The Rolling Plains have more rainfall, and the soils tend to be course and slightly calcareous. Redbed clays and shales occur adjacent to streams, but the soils vary in texture, and coarse sandy soil is also common. The Edwards Plateau soils are often limestone-based with deep clayey soil in the lowlands and upland areas of shallow, stony soils.

Vegetation of the Edwards Plateau includes grasses such as bluestem, grama, Indian grass, wild rye, curly mesquite, and buffalo grass. In addition, live oak, shinnery oak, juniper, and mesquite occur in the rocky uplands. This brushy overgrowth may be intrusive. In the Rolling Plains, typical grasses are similar to those of the Edwards Plateau: bluestem, grama, 
buffalo grass, curly mesquite, wild rye, and western wheat grass. As in the Edwards Plateau to the south, brushy plants often invade uplands and disturbed areas. These plants are commonly mesquite, shinnery oak, and sand sage. Other heavy grasses are also frequent. These include hairy tridens, red grama, Texas grama, gummy lovegrass, and others. Because the Edwards Plateau and the Rolling Plains overlap so much, the margin between the two is somewhat gradual in terms of their floral resources.

A more distinctive difference within Coke County is its geology. In the northern part of Coke County the predominant surface rock is of the Pease River Group of the upper Leonard Formation (Mount et al. 1967:map 27). This formation consists of east-west facies of Permian limestone, shale, and conglomerate limestones (Sellards et al. 1932:150-151). In the southern half of the county exposed outcrops are mainly of the Fredericksburg Group, which consists of a complex variety of Cretaceous sedimentary deposits: sand, sandstone, marls, limestones, and ancient reefs (Sellards et al. 1932:323). Between the Leonard Formation and the Fredericksburg Group there is a narrow strip of rock from the Trinity Group, which underlies Fredericksburg strata. The Trinity Group is made up of sand and conglomerate deposited by a sea which was advancing northward (Sellards et al. 1932:284). Quaternary alluvial deposits occur along the Colorado and its terraces. 


\section{ARCHAEOLOGICAL BACKGROUND}

Previous Research

Archaeological research in Coke County began in the early 1930 s with the excavation of a rockshelter on Oak Creek in the northeastern part of the county (Sayles 1930). The shelter had 4 stratigraphic zones containing hearths, each separated by sterile zones. Petroglyphs forming criss-crossed lines were present on the walls of the shelter. An historic Indian grave was on top of the hill above the rockshelter but has since been looted. Glass beads were visible in the late 1940 s at the grave site (Ray 1948 ). Sayles also conducted a survey of the Abilene area for Gila Pueblo. One of the sites found in his 1932 survey, s:2:1, has been identified tentatively as 41 CK193 (Creel 1984).

In the 1940s, Ray examined 20 sites, mainly in the northeast quarter of the county (Ray 1948), and Jelks and Moorman discussed 12 sites in 1953 (Jelks and Moorman 1953). Ray found hearths to be a common feature with burned rock deposits at campsites. Almost all of the hearths were at or near the surface. Quarry/workshops also were reported. No pottery and very few scrapers were found at any of the sites. Most of the sites Ray discussed appear to be Archaic.

The only intensive scientific investigations within Coke County occurred in the late 1960s in the flood pool of what is now Robert Lee Reservoir (Shafer 1967, 1969, 1971). Shafer reported on 109 sites which were surveyed in 1966. He later excavated several of them. So far, the Robert Lee Reservoir 
project has given archaeologists the most complete picture of prehistory in the county. Shafer found that hearths were the most common feature and were visible at almost every site surveyed (Shafer 1967:70). Most of these hearths were flat and associated with concentrations of burned rock. Other features present on the surface of sites included mussel shell concentrations and rock cairns. Shafer suggested that the cairns might represent markers for isolated burials (Shafer 1967:70). In addition, one site (41CK65) had a circular stone alignment $16 \mathrm{ft}$. in diameter. The interior of the circle was cleared of stone. Shafer suggested that this was a tipi ring.

Artifacts found at Robert Lee Reservoir indicated a diversity of time periods. Projectile points tended to reflect typical Central Texas styles. However, surface collections at the 109 sites resulted in the recovery of 7 beveled knives (Harahay) and 52 keeled end scrapers (Shafer's "Type 1"). These occur in the Toyah Phase of Central Texas, but are more typical of the Plains Village period on the Southern Plains. Pottery was scarce, but the remains of a single vessel were recovered and they are similar to Leon Plain. The apparent mixture of cultural traits from both Central Texas and the Southern Plains is not surprising since the region is peripheral to both culture areas. Shafer also mentions the presence of a blade technology with polyhedral cores. This may be an indication of early occupations in the area. Caches of blades have been found elsewhere in Coke County (Patterson 1980; Tunnell 1978) .

In another study, Riggs (1971) discussed a site near Silver, Texas, which exhibited large rock-lined cooking pits; 8 of these hearths were excavated. 
They averaged $120 \mathrm{~cm}$ in diameter, and were 30-80 cm deep. Although there was plenty of evidence of cooking at the site, there were almost no artifacts found during excavation. Riggs concluded that "excavation outside the hearths failed to produce sufficient material to estimate the use of the area as a habitation locality" (Riggs 1971:48). The site may have been used as a gathering place for some sort of communal cooking activity of short duration and limited scope.

\section{Chronology}

Since prehistoric peoples of the region appear to be closely affiliated with Central Texas, the chronology is similar to that suggested by Weir (1976):

$\begin{array}{lr}\text { Paleo-Indian Stage } & 20,000-9000 \text { B.P. } \\ \text { Archaic Stage } & \\ \text { San Geronimo Phase } & 9000-5000 \text { B.P. } \\ \text { Clear Fork Phase } & 5000-4000 \text { B.P. } \\ \text { Round Rock Phase } & 4000-3000 \text { B.P. } \\ \text { San Narcos Phase } & 3000-1900 \text { B.P. } \\ \text { Twin Sisters Phase } & 1900-1200 \text { B.P. } \\ \text { Late Prehistoric Period } & \\ \text { Austin Focus } & 1200-600 \text { B.P. } \\ \text { Toyah Focus } & 600-200 \text { B.P. }\end{array}$

No diagnostic artifacts were recovered from 41CK193. Therefore, the site could not be assigned to any single time period. 
SITE DESCRIPTION/INVESTIGATION

Methods

An initial uncontrolled surface collection was performed in September 1986. Immediately prior to the November excavations, a brief examination of the site revealed very little cultural material. No further surface collection was made, however. A concentration of burned stone was exposed, and was identified as a hearth feature. This excavation unit was designated Test Unit 4 and was a 2 by 2 meter unit. Four 1 by 1 meter test units were excavated on both sides of SH 158 to determine the horizontal extent of the site and the vertical distribution of the artifacts. These were designated Test Units 1, 2, 3, and 5 (Figure 2).

All units were excavated by hand using shovels and trowels. Walls and floors of each unit-level were scraped with a trowel; and stains, krotovina, roots, and soil texture were noted on standardized excavation forms. Fill from Test Unit 4 was not screened. Fill from the remainder of the test units was shaken through screens made from 1/4-in. hardware cloth. Test Unit 4 was excavated in a single level to expose the feature. The other test units were excavated in $10 \mathrm{~cm}$ levels.

Surface Collection

The surface collection consisted of a "grab-bag" sampling technique in which unmodified flakes were observed but not collected. Most of the cultural material was on the north side of $\mathrm{SH} 158$ and to the west of Pecan Creek. 


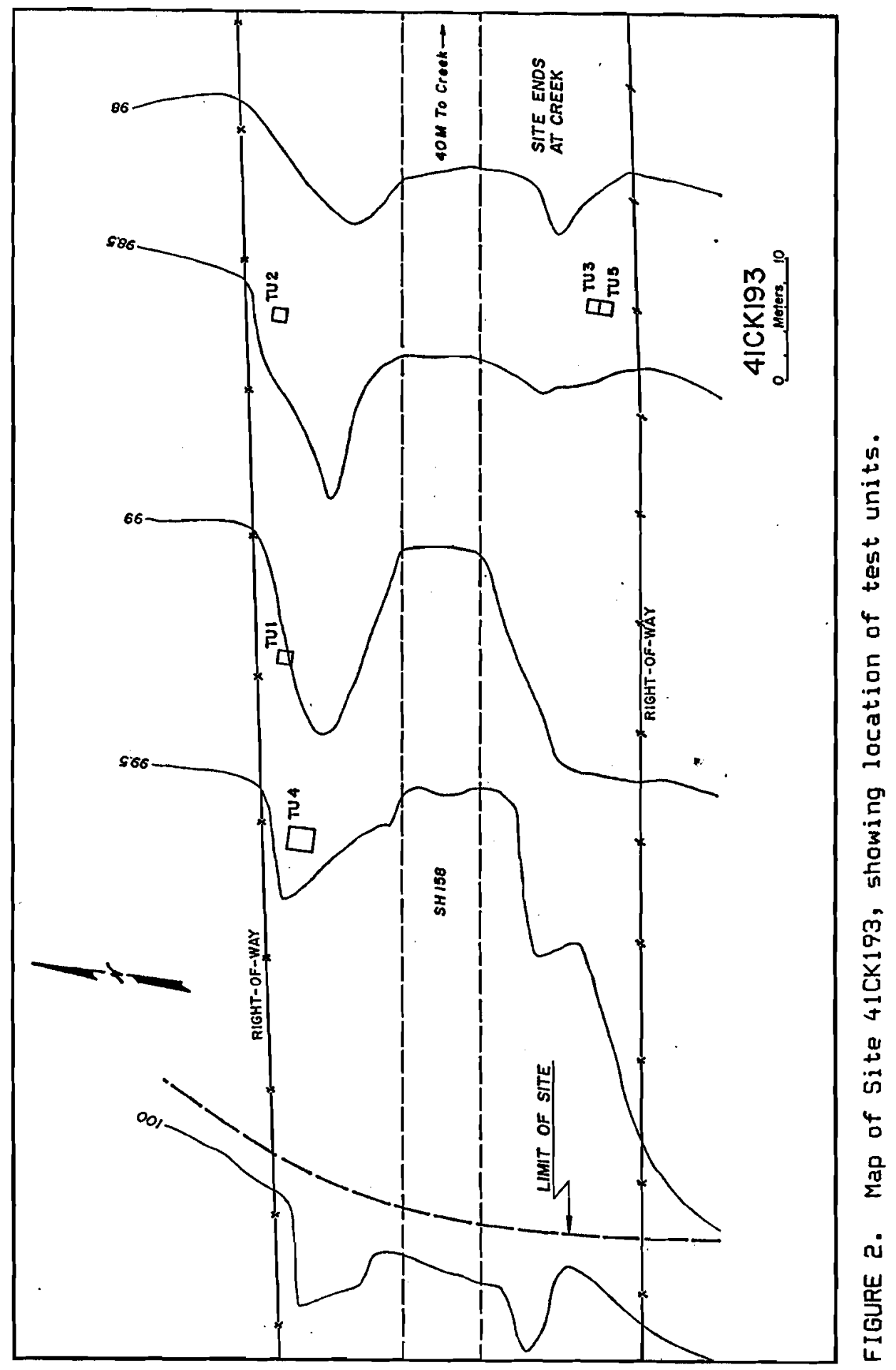


Even though little cultural material was seen, surface visibility was excellent over the entire site.

Artifacts recovered during the uncontrolled surface collection consisted of 3 biface fragments, 1 modified flake, and 1 blade core (Figure 3). One of the biface fragments has been heat-treated. A11 are of locally available chert. The modified flake exhibits unifacial wear along the right lateral edge and was probably used for scraping. The core has had at least 6 flakes removed around its lateral edges. It has a single broad platform at one end and all the flakes were struck from this platform. The edges of the platform have been prepared by grinding.

Test Unit 1

Test Unit 1 was a 1 by 1 meter unit and was excavated to a depth of $30 \mathrm{~cm}$ in three levels of $10 \mathrm{~cm}$ each. The soil was a reddish brown silty loam throughout the unit, with no natural stratigraphy visible. Material in Level 1 included 2 pieces of brown bottle glass, 2 interior chert flakes, and 2 chert chips. Level 2 had only a single secondary chert flake. No material was recovered in Level 3.

Test Unit 2

Test Unit 2 was a 1 by 1 meter unit and was excavated to a depth of $30 \mathrm{~cm}$ in three levels of $10 \mathrm{~cm}$ each. The soil was a reddish brown silty loam throughout the unit, with no natural stratigraphy visible. Material in 

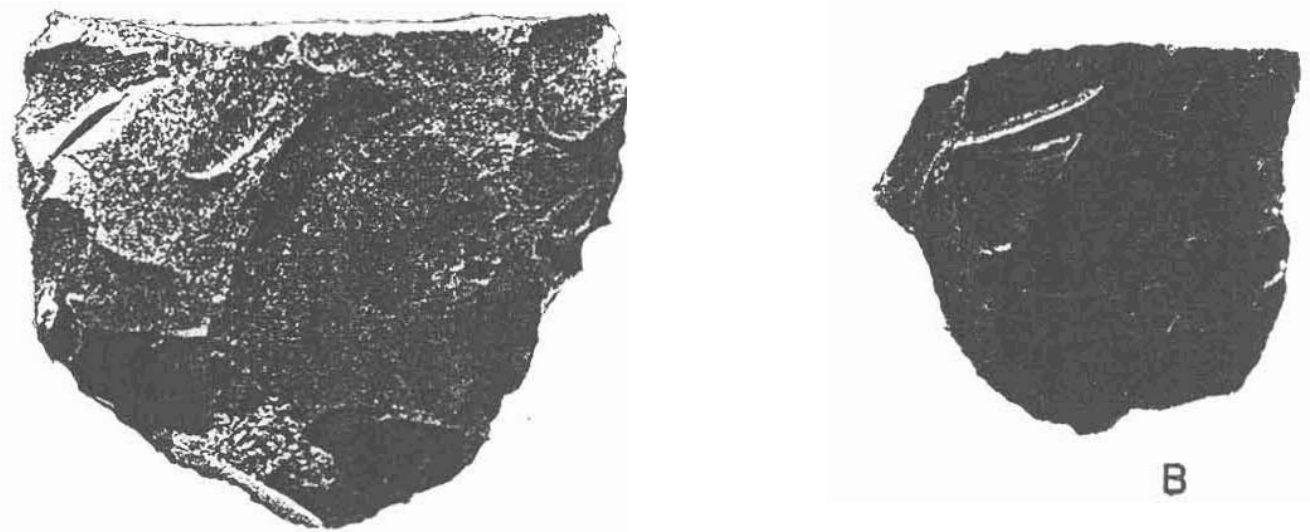

B

A
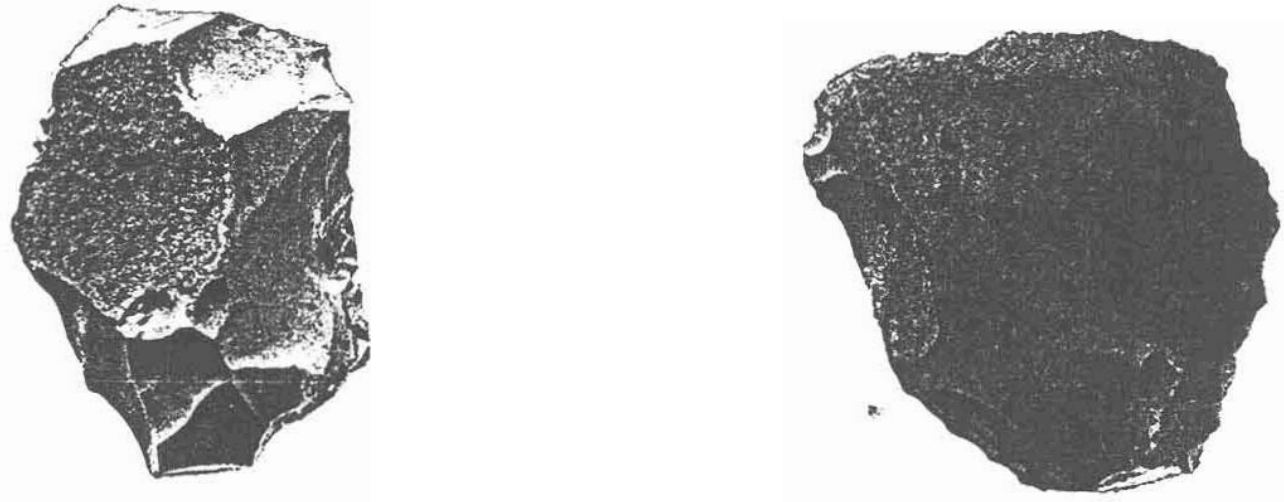

C

D

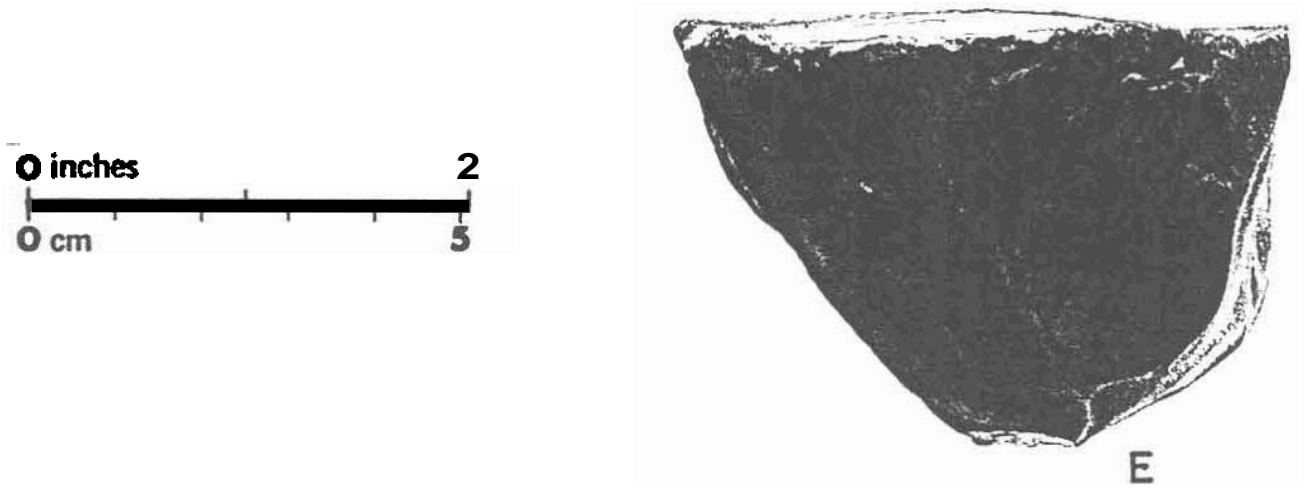

FIGURE 3. Artifacts from surface collection of $41 \mathrm{CK} 193$ A-C, bifaces; D. modified flake; E. core. 
Level 1 consisted of only a single interior chert flake. No material was recovered in Level 2 or Level 3.

Test Unit 3

Test Unit 3 was a 1 by 1 meter unit and was excavated to a depth of $20 \mathrm{~cm}$ in two levels of $10 \mathrm{~cm}$ each. The soil was a reddish brown silty loam throughout the unit, with no natural stratigraphy visible. Occasional flecks of charcoal were visible in the northern part of the unit. Material in Level 1 included a piece of brown bottle glass, 5 interior chert flakes, 2 chert chips, and a chert biface fragment. No cultural material was present in Level 2.

A concentration of rocks appeared in the southern half of the unit. Test Unit 5 was excavated adjacent to Test Unit 3 in order to more completely reveal these rocks (Figure 4). All the rocks were of limestone and did not appear to be burned. A small charcoal stain was visible among the rocks which occurred in the southern half of the unit. Examination of the rocks after Test Unit 5 was excavated indicated that they did not represent a feature, but were the result of road grading activities which had mixed material near the surface and left a line of larger cobbles parallel to the road. This line was clearly visible from Test Units 3 and 5 eastward to the creek.

Test Unit $4 /$ Feature 1

Test Unit 4 was a 2 by 2 meter unit and was excavated as a single $10 \mathrm{~cm}$ 


\section{ICKI93 TEST UNITS 3,5}

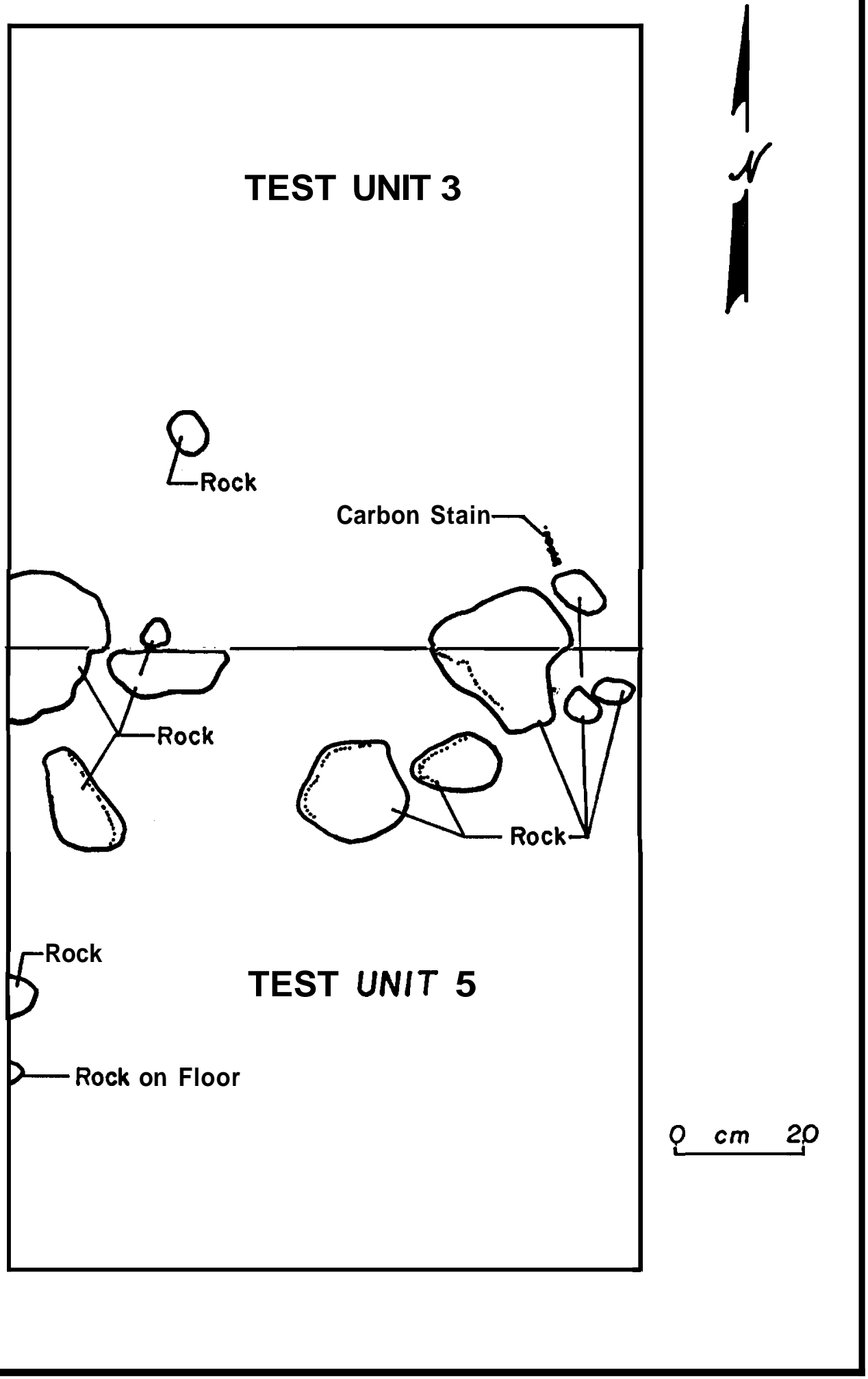

FIGURE 4. Rock alignment from Test Units 3 and 5 Level 1 
level. This test unit was uphill from the other units. The test unit contained the only feature found at the site. The feature was a large limestone hearth within $5 \mathrm{~cm}$ of the present ground surface. It appeared to be largely undisturbed. The rock cluster was 1.4 meters north to south, and 1.5 meters east to west (Figure 5). A central area within the cluster was clear of rocks, but contained a very dark charcoal stain. Soil from this stain was collected. The central area was roughly circular and was about $75 \mathrm{~cm}$ across. Rocks of the cluster were blackened and exhibited what may have been heat-fracture. No artifacts or faunal remains were recovered from the feature.

\section{Test Unit 5}

Test Unit 5 was a 1 by 1 meter unit and was excavated as a single $10 \mathrm{~cm}$ level. This unit was adjacent and to the south of Test Unit 3 (Figure 4). The soil was a reddish brown silty loam throughout the unit, with no natural stratigraphy visible. Occasional flecks of charcoal were visible in the northern part of the unit. Material recovered included an interior chert flake and a blocky chert chip which may be cherty road gravel. The rocks visible in the southern part of Test Unit 3 continued into the northern half of Test Unit 5, but were interpreted to be merely by-products of road grading activities. 


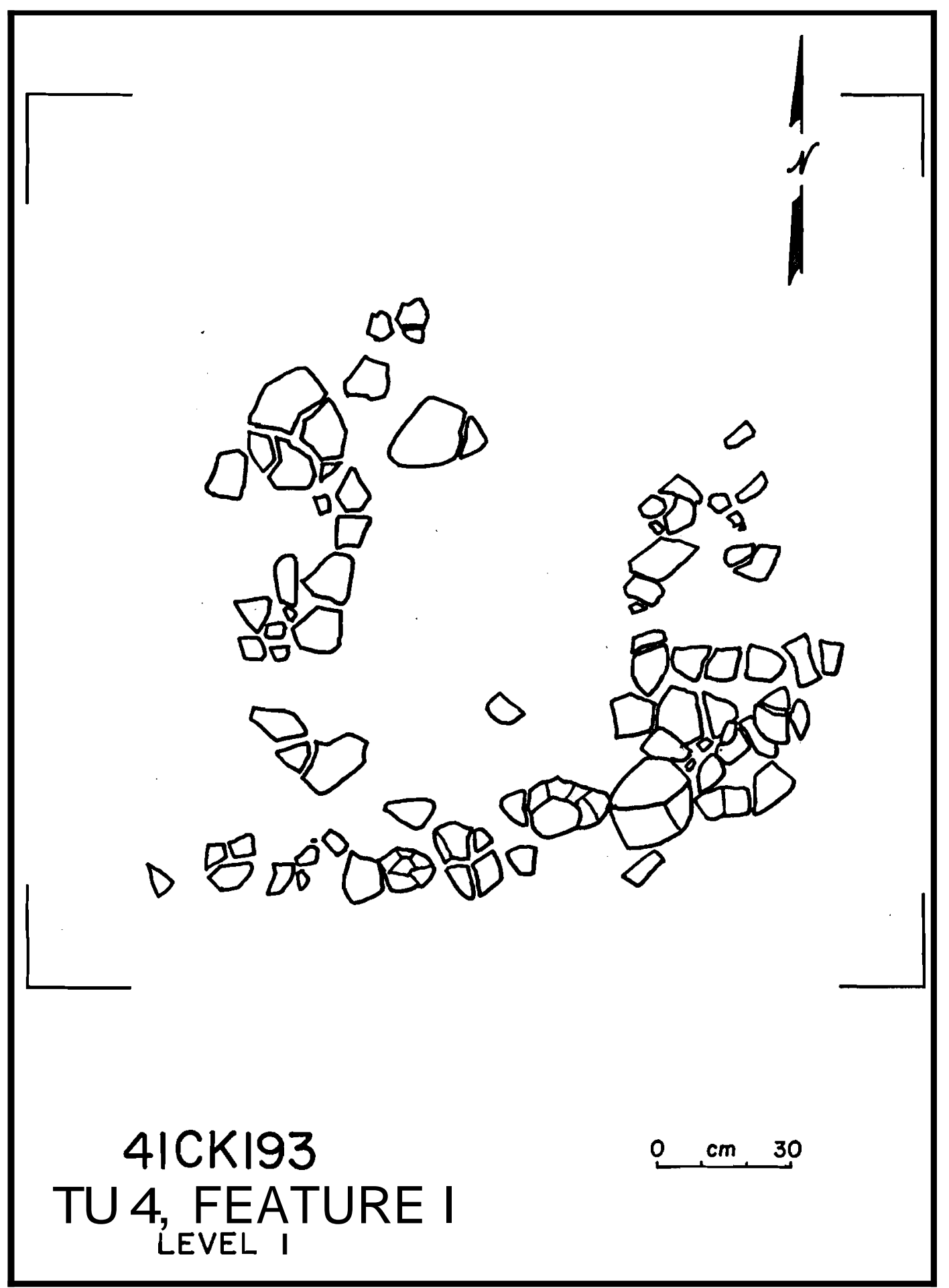

FIGURE 5. Hearth feature from Test Unit 4 


\section{SUMMARY AND RECOMMENDATIONS}

Site 41 CK193 is an extremely shallow site which has been disturbed by previous road maintenance. It represents an ephemeral campsite of unknown prehistoric age. A single feature was present in the form of a large hearth of burned limestone. Cultural material at the site was sparse and consisted mainly of flakes and a few bifaces. Evidence of the site occurs almost entirely within the first $10 \mathrm{~cm}$ of the present surface. Site remains within the right-of-way have been mixed by grading, especially on the south side of the road. A review of the previous archaeological research for the region indicated that sites similar to 41 CK193 are extremely common. Thus, the site is neither well preserved nor significant to our understanding of the prehistory of the region. It is not considered eligible for nomination to the National Register of Historic Places nor to be worthy of a State Archeological Landmark. 
Barnhill, Lloyd J.

1974 Soil Survey of Coke County, Texas. United States Department of Agriculture, Soil Conservation Service, Washington, D.C.

Creel, Darrell

1984 Notes and site form on file at the Texas Archeological Research Laboratory, Balcones Research Center, University of Texas. Austin.

Davis, William B.

1974 The Mammals of Texas. Bulletin 41. Texas Parks and Wildlife Department, Austin.

Gould, F.W. (Editor)

1969 Texas Plants: A Checklist and Ecolosical Summary. Texas Agricultural Experimental Station. Texas A \& M University, College Station.

Jelks, Edward B., and Edward H. Moorman

1953 Survey and Appraisal of the Archaeological Resources of Oak Creek Reservoir, Coke County, Texas. Smithsonian Institution River Basin Surveys, Washington, D.C.

Mount, J. Russell, Frank A. Rayner, Victor M. Schamburger, Jr., Richard C. Peckham, and Fred L. Osborne, Jr.

1967 Reconnaissance Investigation of the Ground-Water Resources of the Colorado River Basin, Texas. Report 51. Texas Water Development Board, Austin.

Patterson, I.W.

1980 Comments on the Gibson Lithic Cache. La Tierra 7(2):26-31.

Ray, Cyrus $\mathbf{N}$.

1948 Survey of Twenty Coke County Sites. Bulletin of the Texas Archeological and Paleontological Society 19:36-56.

Riggs, Aaron D., Jr.

1971 The Walker Site: A Food Preparation Area in Coke County, Texas (41CK137). Transactions of the Sixth Regional Symposium for Southeastern New Mexico and Western Texas, El Paso.

Sayles, E.B.

1930 A Rock Shelter in Coke County. Bulletin of the Texas Archeoloqical and Paleontological Society $2: 33-40$.

Sellards, E.H., W.S. Adkins, and F.B. Plummer

1932 The Geology of Texas. Bulletin 3232. University of Texas, Austin.

Shafer, Harry $J$.

1967 An Archeological Survey of Robert Lee Reservoir, Coke County, Texas. Survey Reports 4. Texas Archeological Salvage Project, University of Texas, Austin. 
Shafer, Harry J. (continued)

1969 Archeological Investigations in the Robert Lee Reservoir Basin, West Central Texas. Papers of the Texas Archeological Salvaqe Proiect 17. Texas Archeological Salvaqe Project, University of Texas, Austin.

1971 Investigations into South Plains Prehistory, West Central Texas: Salvage Archeology in the Robert Lee Reservoir District. Papers of the Texas Archeoloqical Salvage Proiect 20. Texas Archeological Salvage Project, University of Texas, Austin.

Tunnell, Curtis

1978 The Gibson Lithic Cache from West Texas. Report 30. Texas Historical Commission, Office of the State Archaeologist, Austin.

Weir, Frank A.

1976 The Central Texas Archaic. Ph.D. dissertation, Department of Anthropology, Washington State University, Pullman. 